\title{
Advanced Oxidation of Reactive Yellow 17 Dye: a Comparison between Fenton, Photo-Fenton, Electro-Fenton, Anodic Oxidation and Heterogeneous Photocatalysis Processes
}

\author{
A. Sennaoui ${ }^{a}$, S. Alahiane ${ }^{a}$, F. Sakr ${ }^{a}$, A. Assabbane ${ }^{a, *}$, \\ EI H. Ait Addi ${ }^{b}$ and M. Hamdani ${ }^{a}$ \\ ${ }^{a}$ Laboratory of Electrochemistry, Catalysis and Environment, Faculty of Science, \\ Ibn Zohr University, Agadir, Morocco \\ ${ }^{b}$ Team of Biotechnology, Energy and Environment, Superior School of Technology, \\ Ibn Zohr University, Agadir, Morocco
}

\begin{abstract}
In this study, Fenton, photo-Fenton, electro-Fenton, anodic oxidation and heterogeneous photocatalysis advanced oxidation processes (AOPs) have been applied to degrade reactive yellow 17 (RY17) dye in an aqueous solution. Comparison of these techniques for oxidation efficiency was undertaken. The results showed better performance with the use of a heterogeneous photocatalysis process. Degradation efficiency was observed in the order: heterogeneous photocatalysis $>$ photo-Fenton $=$ electro-Fenton $>$ anodic oxidation > Fenton. Even though complete RY17 dye degradation has been observed with heterogeneous photocatalysis, photo-Fenton and electro-Fenton processes, the heterogeneous photocatalysis process has showed complete RY17 dye removal within $30 \mathrm{~min}$, whereas in the case of photo-Fenton and electro-Fenton processes, no RY17 was detected after $60 \mathrm{~min}$. Fenton and anodic oxidation processes have required more time for complete RY17 degradation. The RY17 degradation kinetics was studied and compared in all processes. The results showed higher rate constant values for heterogeneous photocatalysis $\left(\mathrm{k}_{\mathrm{app}}=0.2 \mathrm{~min}^{-1}\right)$, photo-Fenton $\left(\mathrm{k}_{\mathrm{app}}=0.126 \mathrm{~min}^{-1}\right)$ and electro-Fenton $\left(\mathrm{k}_{\mathrm{app}}=0.122 \mathrm{~min}^{-1}\right)$ processes.
\end{abstract}

Keywords: RY17 degradation; Fenton's processes; anodic oxidation; heterogeneous photocatalysis; degradation kinetics.

\section{Introduction}

Azo dyes constitute the largest and most versatile class of synthetic dyes used for textile dying, and other industrial applications [1]. Unfortunately, azo dyes present in the wastewater are normally unaffected by conventional treatment processes. Their persistence is mainly due to sulfo and azo groups, which do not

\footnotetext{
* Corresponding author. E-mail address: aassabbane@yahoo.fr
} 
naturally occur, making the dyes xenobiotic and recalcitrant to oxidative degradation [2].

Treatment methods involving adsorption, coagulation/flocculation and electrocoagulation are also not able to completely remove the pollutants, and can generate secondary environment loading, in the form of sludge [3]. As a result of these shortcomings, and for the past few decades, alternate technologies, known as Advanced Oxidation Processes (AOPs), have been extensively explored for the effective degradation of these compounds [4]. AOPs are chemical, photocatalytic and electrochemical methods based on the in situ generation of hydroxyl radical $\left({ }^{\circ} \mathrm{OH}\right)$. This species is the second strongest oxidant known after fluorine, and has an equally high standard reduction potential $\left(\mathrm{E}^{\circ}\left({ }^{\circ} \mathrm{OH} / \mathrm{H}_{2} \mathrm{O}\right)=\right.$ $2.80 \mathrm{~V}$ vs. SHE) that can non-selectively react with most organic pollutants up to their total mineralization (conversion into $\mathrm{CO}_{2}$, water and inorganic ions) [5].

As one of AOPs, photocatalytic treatment of wastewater is an emerging technology. In this process, the solution is illuminated with UV irradiation in the presence of a suitable photocatalyst, mainly titanium dioxide $\left(\mathrm{TiO}_{2}\right)$. It can absorb UV light to generate electron-hole pairs. Then, reactive oxygen species (ROS), particularly hydroxyl radicals, are generated by photo-stimulated reactions on $\mathrm{TiO}_{2}$ surface (Eqs. 1-6) [6]. Thus, complete pollutants mineralization can occur by the heterogeneous photocatalysis process $\left(\mathrm{UV} / \mathrm{TiO}_{2}\right)$ [7].

$$
\begin{gathered}
\mathrm{TiO}_{2} \rightarrow \mathrm{e}^{-}+\mathrm{h}^{+} \\
\mathrm{e}^{-}+\mathrm{O}_{2} \text { (ads) } \rightarrow \mathrm{O}_{2}^{-}(\text {ads }) \\
\mathrm{e}^{-}+\mathrm{H}^{+}(\text {ads }) \rightarrow{ }^{\circ} \mathrm{H}(\text { ads }) \\
\mathrm{O}_{2}^{-} \text {(ads) }+\mathrm{H}^{+} \rightarrow \mathrm{HOO}^{\cdot} \\
2 \mathrm{HOO} \rightarrow \mathrm{H}_{2} \mathrm{O}_{2}+\mathrm{O}_{2} \\
\left.\mathrm{H}_{2} \mathrm{O}_{2}+{ }^{\circ} \mathrm{O}_{2}^{-} \text {(ads }\right) \rightarrow{ }^{\circ} \mathrm{OH}+\mathrm{OH}^{-}+\mathrm{O}_{2}
\end{gathered}
$$

The other advanced oxidation process is Fenton, which is initiated by hydroxyl radicals formation during a Fenton reaction (Eq. 7) [8].

$$
\mathrm{Fe}^{2+}+\mathrm{H}_{2} \mathrm{O}_{2} \rightarrow \cdot \mathrm{OH}+\mathrm{Fe}^{3+}+\mathrm{OH}^{-}
$$

The simultaneous emission of photons enhances the Fenton reaction rate, and even recalcitrant organic acid by-products achieve complete mineralization, through the so-called "photo-Fenton process". This is attributed to the regeneration of the required Fe(II) species (Eq. 8). More significantly, low molecular weight organic acids, that are strongly complexed by $\mathrm{Fe}(\mathrm{III})$, and thus limit their oxidation by strong ${ }^{\circ} \mathrm{HO}$ radicals, are also destroyed through intramolecular ligand to metal charge transfer, to yield Fe(II) ions as well (Eq. 9) [9].

$$
\mathrm{Fe}(\mathrm{III}) \mathrm{OH}^{2+}+\mathrm{h} v \rightarrow \mathrm{Fe}(\mathrm{II})+{ }^{\cdot} \mathrm{HO}
$$




$$
\mathrm{Fe}(\mathrm{III})\left(\mathrm{RCO}_{2}\right)^{2+}+\mathrm{h} v \rightarrow \mathrm{Fe}(\mathrm{II})+\mathrm{CO}_{2}+\mathrm{R}^{\cdot}
$$

The advanced oxidation electrochemical processes are used to eliminate or reduce the necessary quantities in chemical reagents, by directly producing the oxidants $\left({ }^{\circ} \mathrm{OH}\right)$ in the reaction medium, through direct (anodic oxidation) or indirect (electro-Fenton, via the Fenton reagent) electrochemical methods [10]. The most usual conventional electrochemical method for organic pollutants destruction is anodic oxidation. This method is based on the generation of adsorbed hydroxyl radicals $\left({ }^{\circ} \mathrm{OH}\right)$ onto the anode surface of a high oxygen overvoltage, by water oxidation (Eq. 10) [11]:

$$
\mathrm{H}_{2} \mathrm{O} \rightarrow{ }^{\cdot} \mathrm{OH}_{\mathrm{ads}}+\mathrm{H}^{+}+\mathrm{e}^{-}
$$

In the electro-Fenton process, $\mathrm{Fe}^{2+}$ and $\mathrm{H}_{2} \mathrm{O}_{2}$ are simultaneous produced by reduction of air oxygen (Eq. 11) and ferric ions (Eq. 12) at the cathode. Then, hydroxyl radicals are formed in a catalytic mode via electrochemically generated Fenton's reagent (Eq. 7) [12].

$$
\begin{gathered}
\mathrm{O}_{2}+2 \mathrm{H}^{+}+2 \mathrm{e}^{-} \rightarrow \mathrm{H}_{2} \mathrm{O}_{2} \\
\mathrm{Fe}^{3+}+\mathrm{e}^{-} \rightarrow \mathrm{Fe}^{2+}
\end{gathered}
$$

The objective of this study is to present the results obtained for the RY17 dye degradation through advanced oxidation processes: chemical (Fenton), electrochemical (direct and indirect) and photochemical (homogeneous and heterogeneous), in order to show the utility of these processes on azo dye (RY17) degradation, and to carry out a comparative study of these different advanced oxidation processes.

\section{Experimental \\ Reagents}

The reactive yellow 17 (RY17) is a synthetic organic dye used in textile industries. The molecular structure and other properties of RY 17 are given in Table 1.

Ferrous sulphate heptahydrate $\left(\mathrm{FeSO}_{4}, 7 \mathrm{H}_{2} \mathrm{O}\right)$, sodium sulfate $\left(\mathrm{Na}_{2} \mathrm{SO}_{4}\right)$, sulphuric acid $\left(\mathrm{H}_{2} \mathrm{SO}_{4}\right)$ and nitric acid $\left(\mathrm{HNO}_{3}\right)$ were purchased from Fluka, Labosi and Riedel-de Haen, respectively. Also, hydrogen peroxide $\left(\mathrm{H}_{2} \mathrm{O}_{2}, 30 \%\right)$, sodium hydroxide $(\mathrm{NaOH})$ and ethanol $\left(\mathrm{C}_{2} \mathrm{H}_{6} \mathrm{O}\right)$ were obtained from Carlo Erba reagents, Pharmac and Merck, respectively. Acetonitrile and water were of ultra gradient grade for HPLC, supplied by VWR Chemicals (Prolabo).

All these chemical substances were of reagent grade, and used without further purification. All the solutions were prepared from distilled water, and were conducted at room temperature.

The immobilized photocatalyst used in this study is titanium dioxide PC500 of Millennium inorganic chemicals S.A brand (anatase: > 99\%, specific surface area 
$350-400 \mathrm{~m}^{2} / \mathrm{g}$, crystallites mean size $=5-10 \mathrm{~nm}$ ). Titania PC500 was coated on non-woven fibers (natural and synthetic fibers with $254 \mu \mathrm{m}$ of thickness) using an inorganic binder. The binder was an aqueous dispersion of colloidal $\mathrm{SiO}_{2}$. A specific surface area extender (zeolite, $2000 \mathrm{~m}^{2} / \mathrm{g}$ ) was used to increase the photocatalyst adsorption properties.

Table 1. RY17 dye properties.

\begin{tabular}{|c|c|}
\hline Name & Reactive yellow 17 \\
\hline Family & Reactive azo dye \\
\hline Molecular formula & $\mathrm{C}_{20} \mathrm{H}_{20} \mathrm{~N}_{4} \mathrm{O}_{12} \mathrm{~S}_{3} .2 \mathrm{~K}$ \\
\hline Molecular weight $(\mathrm{g} / \mathrm{mol})$ & 682.77 \\
\hline$\lambda_{\max }(\mathrm{nm})$ & 408 \\
\hline & \\
Molecular structure & \\
& \\
\hline
\end{tabular}

\section{Instruments and experimental procedures}

Fenton and photo-Fenton processes

RY17 solutions with different concentrations were prepared in distilled water. They were then homogenized by stirring, until the dye was totally dissolved. The reaction mixture's $\mathrm{pH}$ was adjusted to 3 , by adding sulfuric acid, and measured by a $\mathrm{pH}$-meter. The dye oxidation was achieved by Fenton's reagent, composed of a $\mathrm{FeSO}_{4} .7 \mathrm{H}_{2} \mathrm{O}$ and $\mathrm{H}_{2} \mathrm{O}_{2}$ mixture. The required $\mathrm{Fe}^{2+}$ and $\mathrm{H}_{2} \mathrm{O}_{2}$ quantities were simultaneously added in the solution. The experimental device was a perfectly agitated and cylindrical reactor, in which a $500 \mathrm{~mL}$ solution was studied.

Specifically, for the photochemical experiments, a high pressure mercury lamp (Philips HPK, $125 \mathrm{~W}$ ), which emitted a maximum radiation at $365 \mathrm{~nm}$, was used as radiation source. It was located in the reactor in axial position inside a quartz sleeve. This photoreactor (Fig. 1(A)) contains a double wall for the circulation of the system's cooling water. The outside of the photoreactor was covered with an aluminium sheet. At the top, the photoreactor has inlets and ports for feeding reactants and withdrawing samples.

\section{Electro-Fenton and anodic oxidation processes}

RY17 degradation by the electro-Fenton process was performed in a $0.5 \mathrm{~L}$ undivided electrochemical cell, equipped with two electrodes (Fig. 1(B)). The working electrode was a carbon felt piece $\left(6 \times 8 \times 0.5 \mathrm{~cm}^{3}\right)$, a flexible, resistant and easy handling material. The counter electrode was a boron-doped diamond (BDD) thin film $\left(5 \times 8 \times 0.2 \mathrm{~cm}^{3}\right)$. The applied current between these electrodes was available by a stabilized supply source. Before the electrolysis, compressed air was bubbled for $10 \mathrm{~min}$ through the cell, to saturate the aqueous solution in oxygen. A sodium sulfate concentration of $50 \mathrm{mM}\left(\mathrm{Na}_{2} \mathrm{SO}_{4}\right)$ was added to the solution as the supporting electrolyte. The iron sulfate $\left(\mathrm{FeSO}_{4}, 7 \mathrm{H}_{2} \mathrm{O}\right)$ catalyzing the Fenton reaction was added to the reaction medium before the electrolysis beginning. The-solutions' $\mathrm{pH}$ was adjusted to 3 by sulphuric acid $\left(10^{-3} \mathrm{M}\right)$, to 
avoid the precipitation of ferric ions in the form of hydroxides. The solutions were homogenized by a magnetic stirrer (600 rev/min).

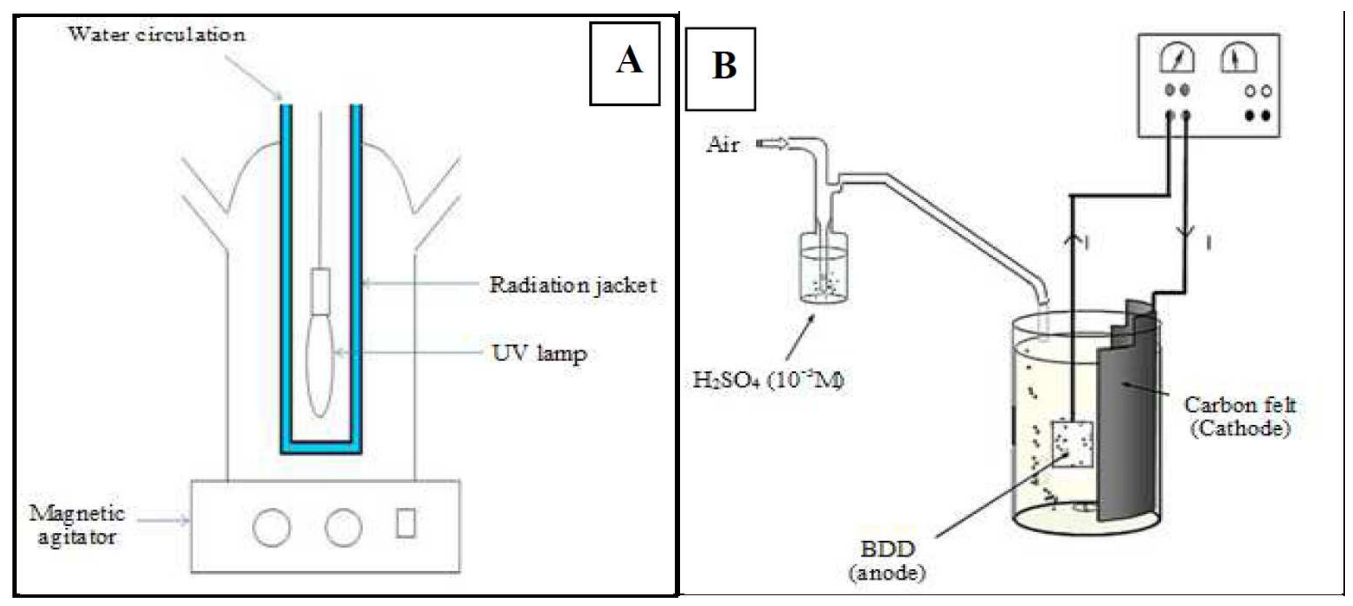

Figure 1. The experimental set-up for: (A) photochemical and (B) electrochemical experiments.

\section{Electro-Fenton and anodic oxidation processes}

RY17 degradation by the electro-Fenton process was performed in a $0.5 \mathrm{~L}$ undivided electrochemical cell, equipped with two electrodes (Fig. 1(B)). The working electrode was a carbon felt piece $\left(6 \times 8 \times 0.5 \mathrm{~cm}^{3}\right)$, a flexible, resistant and easy handling material. The counter electrode was a boron-doped diamond (BDD) thin film $\left(5 \times 8 \times 0.2 \mathrm{~cm}^{3}\right)$. The applied current between these electrodes was available by a stabilized supply source. Before the electrolysis, compressed air was bubbled for $10 \mathrm{~min}$ through the cell, to saturate the aqueous solution in oxygen. A sodium sulfate concentration of $50 \mathrm{mM}\left(\mathrm{Na}_{2} \mathrm{SO}_{4}\right)$ was added to the solution as the supporting electrolyte. The iron sulfate $\left(\mathrm{FeSO}_{4}, 7 \mathrm{H}_{2} \mathrm{O}\right)$ catalyzing the Fenton reaction was added to the reaction medium before the electrolysis beginning. The-solutions' $\mathrm{pH}$ was adjusted to 3 by sulphuric acid $\left(10^{-3} \mathrm{M}\right)$, to avoid the precipitation of ferric ions in the form of hydroxides. The solutions were homogenized by a magnetic stirrer (600 rev/min).

RY17 degradation by the anodic oxidation process was carried out in the same electrochemical cell as the electro-Fenton process. This process does not require the use of a catalyst $\left(\mathrm{FeSO}_{4}, 7 \mathrm{H}_{2} \mathrm{O}\right)$.

\section{Heterogeneous photocatalysis}

The photodegradation experiments were carried out by loading $500 \mathrm{~mL}$ of the RY17 dye solutions of known titre in the photoreactor (Fig. 1(A)), inside recovered by the photocatalytic $\mathrm{TiO}_{2}$ supported on paper $(11 \mathrm{~cm}$ x $25 \mathrm{~cm})$ (equivalent to $1 \mathrm{~g}$ of $\mathrm{TiO}_{2}$ ).

The $\mathrm{pH}$ was adjusted to a given value in the range of $3-11.5$ by $\mathrm{HNO}_{3}(1 \mathrm{~N})$ or $\mathrm{NaOH}(1 \mathrm{~N})$ addition.

The mixture was kept under constant magnetic stirring in the dark, during an hour and a half, so that the RY17 adsorption equilibrium on the catalyst surface was established. Then, the reaction mixture was exposed to UV radiation. Experiments were performed at room temperature. 


\section{Analytical methods}

The solution's pH was determined using a pH meter (HANNA instruments). Samples were collected at regular time intervals, and before analysis they were filtered with Sartolon polyamide $(0.45 \mu \mathrm{m})$ filters.

\section{$U V$-Vis spectrophotometer}

The RY17 concentration was measured using a UV-Vis spectrophotometer (Jasco V-630) by measuring the absorption at a $408 \mathrm{~nm}$ wavelength.

The percentage discoloration efficiency (DE) percentage was calculated as follows:

$$
\% D E=\left(A_{0-} A_{\mathrm{t}}\right) / A_{0} \times 100
$$

where $A_{0}$ and $A_{t}$ are the absorbance at initial time, and time $t$ at $\lambda \max =408 \mathrm{~nm}$, respectively.

\section{High-performance liquid chromatography (HPLC)}

The RY17 concentration was determined by high-performance liquid chromatography (Shimadzu LC-SPD20A) with a Shimadzu UV-2A detector. The mobile phase consisted of a $70 \%$ water and $30 \%$ acetonitrile mixture.

Separation was achieved with a Nucleosil C18 column $(150 \mathrm{~mm} \times 4.6 \mathrm{~mm})$, at a 1 $\mathrm{mL} \min ^{-1}$ flow rate. The detection wavelength was $408 \mathrm{~nm}$.

\section{Degradation kinetics}

Hydroxyl radicals are non-selective reagents, highly reactive on organic compounds and, therefore, not accumulative in the middle, because they have a very short lifetime [13].

Thus, the quasi-stationary state can be applied to the hydroxyl radicals concentration, and the dyes hydroxylation reaction can be likened to a pseudo first order kinetics.

$$
\begin{gathered}
\text { Dye }+{ }^{\circ} \mathrm{OH} \\
\mathrm{V}=-(\mathrm{d}[\text { dye }]) / \mathrm{d} t=\mathrm{K}_{\mathrm{abs}(\mathrm{dye})}\left[\text { dye }^{\prime}\right]\left[H O^{\circ}\right]=\mathrm{K}_{\mathrm{app}(\text { dye })}[\text { dye }]
\end{gathered}
$$

By integrating the Eq. (14), the following equation could be obtained:

$$
\operatorname{Ln}[d y e]_{0} /[d y e]_{\mathrm{t}}=\mathrm{K}_{\mathrm{app}(\mathrm{dye})} t
$$

Thus, the graph $\operatorname{Ln}[d y e]_{0} /[d y e]_{\mathrm{t}}=f(t)$ is used to determine the apparent rate constant of the RY17 dye oxidation reaction with hydroxyl radicals.

\section{Results and discussion}

\section{RY17 degradation by $\mathrm{UV}, \mathrm{UV} / \mathrm{H}_{2} \mathrm{O}_{2}$, Fenton and photo-Fenton processes}

Reactive yellow 17 (RY17) dye decolorization in an aqueous solution by the Fenton oxidation process has been studied on different experimental conditions, including $\mathrm{Fe}^{2+}, \mathrm{H}_{2} \mathrm{O}_{2}$, and initial dye concentrations, and reaction time. 
The effects of these parameters have been studied, and optimum operational conditions of these processes were found (Fig. 2).

Maximum decolorization (90\%) efficiencies were achieved for $0.1 \mathrm{mM} \mathrm{of} \mathrm{H}_{2} \mathrm{O}_{2}$, $0.01 \mathrm{mM}$ of $\mathrm{Fe}^{2+}$ and $10 \mathrm{mg} / \mathrm{L}$ of dye concentration, after $3 \mathrm{~h}$ of reaction time [14].

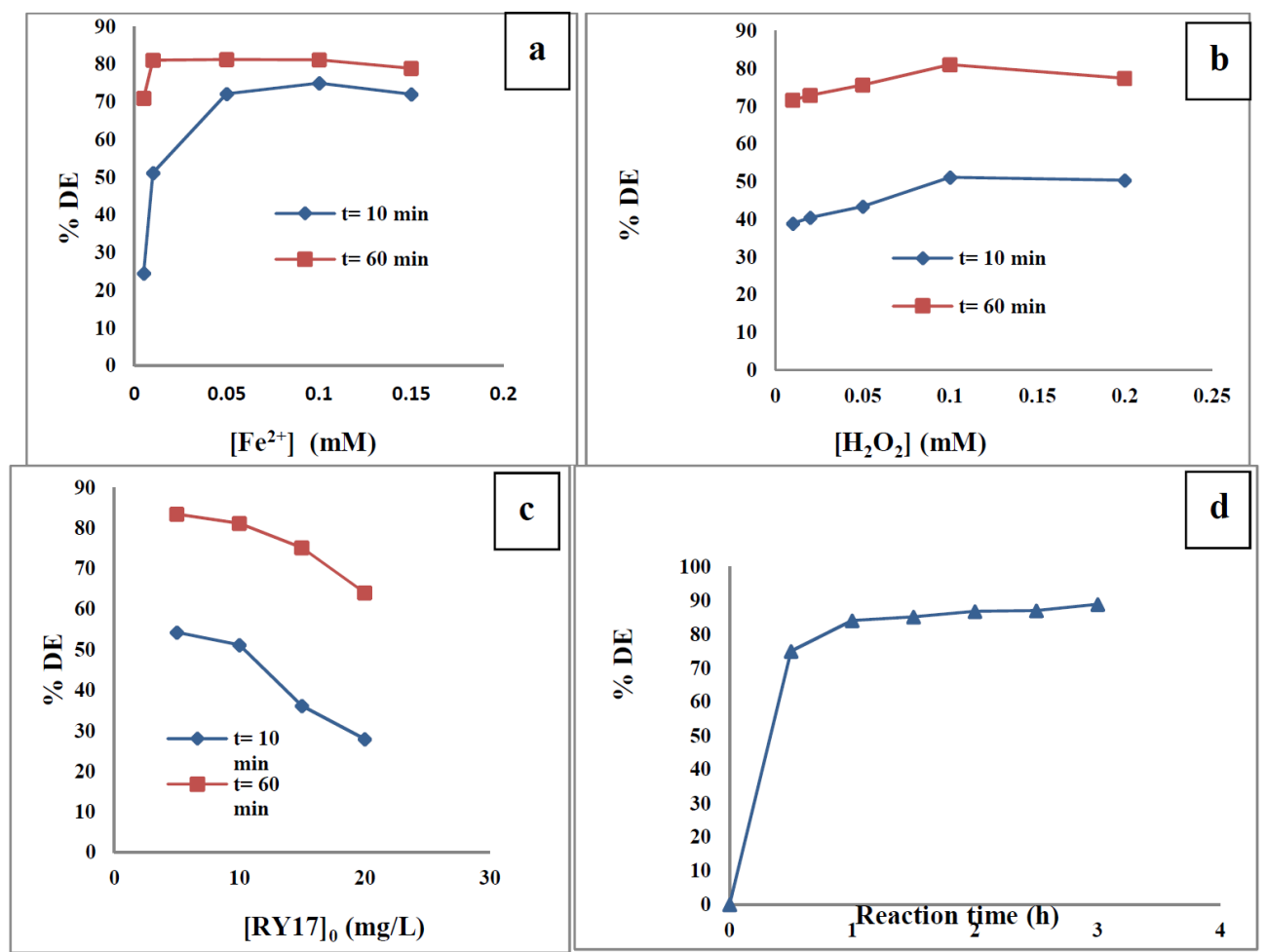

Figure 2. Effect of initial concentrations of (a) $\mathrm{Fe}^{2+}$, (b) $\mathrm{H}_{2} \mathrm{O}_{2}$ and (c) the dye, and (d) the effect of reaction time on the $\mathrm{RY} 17$ discoloration efficiency $\left(\mathrm{pH}=3 ; \mathrm{T}=22^{\circ} \mathrm{C}\right)$.

(a) $[\mathrm{RY} 17]_{0}=10 \mathrm{mg} / \mathrm{L},\left[\mathrm{H}_{2} \mathrm{O}_{2}\right]=0.1 \mathrm{mM}$; (b) $[\mathrm{RY} 17]_{0}=10 \mathrm{mg} / \mathrm{L},\left[\mathrm{FeSO}_{4}\right]=0.01$ $\mathrm{mM}$; (c) $\left[\mathrm{FeSO}_{4}\right]=0.01 \mathrm{mM},\left[\mathrm{H}_{2} \mathrm{O}_{2}\right]=0.1 \mathrm{mM}$; (d) $[\mathrm{RY} 17]_{0}=10 \mathrm{mg} / \mathrm{L},\left[\mathrm{Fe}^{2+}\right]=0,01$ $\mathrm{mM},\left[\mathrm{H}_{2} \mathrm{O}_{2}\right]=0,1 \mathrm{mM}$.

RY17 degradation by direct photolysis, the combination of UV-radiation with $\mathrm{H}_{2} \mathrm{O}_{2}\left(\mathrm{UV} / \mathrm{H}_{2} \mathrm{O}_{2}\right)$, and the photo-Fenton process $\left(\mathrm{UV} / \mathrm{F}^{2+} / \mathrm{H}_{2} \mathrm{O}_{2}\right)$ were realized at the optimal reagent concentration established by the Fenton process, that is, $\left[\mathrm{Fe}^{2+}\right]=0.01 \mathrm{mM},\left[\mathrm{H}_{2} \mathrm{O}_{2}\right]=0.1 \mathrm{mM},[\mathrm{RY} 17]=10 \mathrm{mg} / \mathrm{L}, \mathrm{pH}=3$, and $\mathrm{T}=25^{\circ} \mathrm{C}$. Results (Fig. 3) showed that the use of the UV treatment alone (direct photolysis) was not sufficient in RY17 degradation, because the degradation efficiency after 60 min of treatment was only $15 \%$.

The combined action of $\mathrm{UV}$ and $\mathrm{H}_{2} \mathrm{O}_{2}$ caused $65 \%$ degradation in $60 \mathrm{~min}$. Regarding the photo-Fenton process, 98\% degradation was obtained at $60 \mathrm{~min}$. The $\mathrm{UV} / \mathrm{H}_{2} \mathrm{O}_{2}$ system is an indirect photochemical process based on the $\mathrm{H}_{2} \mathrm{O}_{2}$ photolysis by UV light (UV $\leq 300 \mathrm{~nm}$ ), to yield hydroxyl radicals [15]; adding $\mathrm{Fe}^{2+}$ to this system enhanced the dye oxidation rate, by the generation of hydroxyl radicals in the aqueous medium, through the Fenton process main reaction between iron (II) and hydrogen peroxide. 


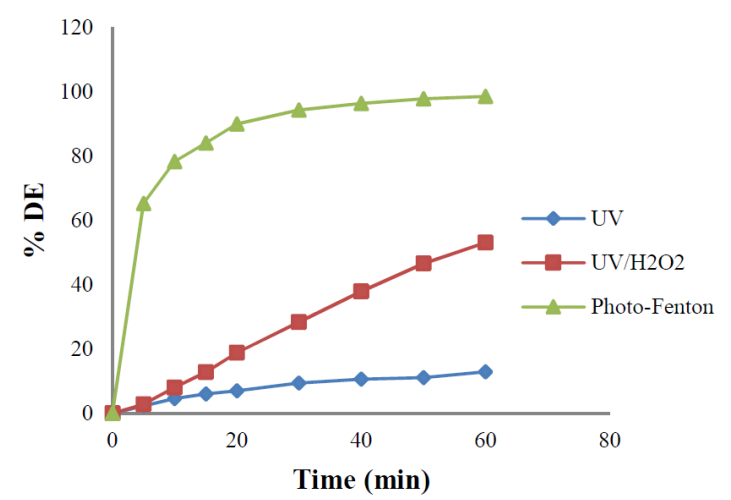

Figure 3. Evolution of the discoloration efficiency during $\mathrm{UV}, \mathrm{UV} / \mathrm{H}_{2} \mathrm{O}_{2}$ and photoFenton RY17 treatments. $[\mathrm{RY} 17]_{0}=10 \mathrm{mg} / \mathrm{L},\left[\mathrm{H}_{2} \mathrm{O}_{2}\right]=0.1 \mathrm{mM},\left[\mathrm{Fe}^{2+}\right]=0.01 \mathrm{mM}, \mathrm{pH}$ $=3, \mathrm{~T}=22{ }^{\circ} \mathrm{C}$.

\section{RY17 degradation by electrochemical advanced oxidation processes}

\section{Electro-Fenton process}

The degradation of reactive yellow 17 (RY17) was investigated using electroFenton system. A $2^{4}$ factorial design, considering the initial $\mathrm{Fe}^{2+}$ and dye concentrations, the applied current and the electrolysis time as variable independents, was used to analyze the process by response surface methodology. The maximum decolorization efficiency attained $99.94 \%$, in the response of variations in the experimental conditions, which confirms the electro-Fenton process ability, and also the importance of process modeling. ANOVA analysis confirmed that all variables have had significant influence on the model response, and showed a high determination value coefficient $\left(\mathrm{R}^{2}=0.9938\right)$. Graphical response surface and contour plots were used to locate the optimum point. Optimum values of process variables for the maximum decolorization efficiency $(100 \%)$ were: $\mathrm{Fe}^{2+}$ concentration $=0.04 \mathrm{mM}$, applied current $=100$ $\mathrm{mA}, \mathrm{RY} 17$ concentration $=5 \mathrm{mg} / \mathrm{L}$ and electrolysis time $=30 \mathrm{~min}$ [16].

Under the experimental conditions thus determined, RY17 disappearance and discoloration were followed by HPLC and UV-visible. Fig. 4 shows the monitoring of the RY17 aqueous solution evolution during electrolysis by UVvisible spectroscopy. This figure shows that the disappearance of this color by the electro-Fenton process is fast. The absorbance peak at $\lambda=408 \mathrm{~nm}$ gradually decreases, and then completely disappears after $30 \mathrm{~min}$. This significant peak reduction can be likened to the cleavage of the bond $-\mathrm{N}=\mathrm{N}-$, the most active site for hydroxyl radicals oxidative attack.

Furthermore, the UV spectrum shows that the starting dye disappearance, following the hydroxyl radicals oxidizing action, is accompanied by the formation of intermediate aromatic compounds, which absorb about 230 and 294 $\mathrm{nm}$. These latter, in turn, suffer the hydroxyl radicals degrading action.

The treated solutions HPLC analysis has also enabled to follow this colorant kinetics disappearance. As shown in Fig. 5, RY17 peak $\left(t_{r}=1.28 \mathrm{~min}\right)$ gradually decreases during electrolysis, and then completely disappears after $30 \mathrm{~min}$ treatment. 


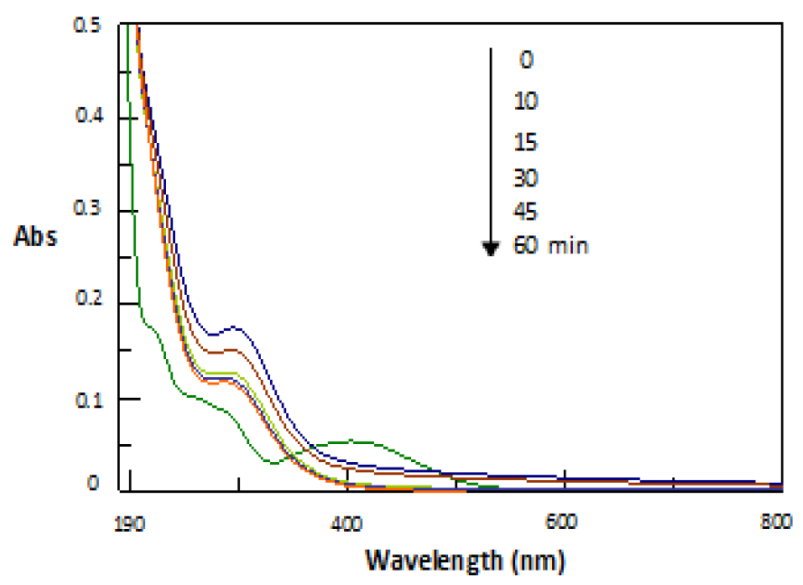

Figure 4. Variations of UV-Vis absorption spectra for RY17. [RY17] $]_{0}=5 \mathrm{mg} / \mathrm{L} ;\left[\mathrm{Fe}^{2+}\right]$ $=0.04 \mathrm{mM} ; \mathrm{I}=100 \mathrm{~mA} ; \mathrm{pH}=3 ; \mathrm{T}=22{ }^{\circ} \mathrm{C}$.
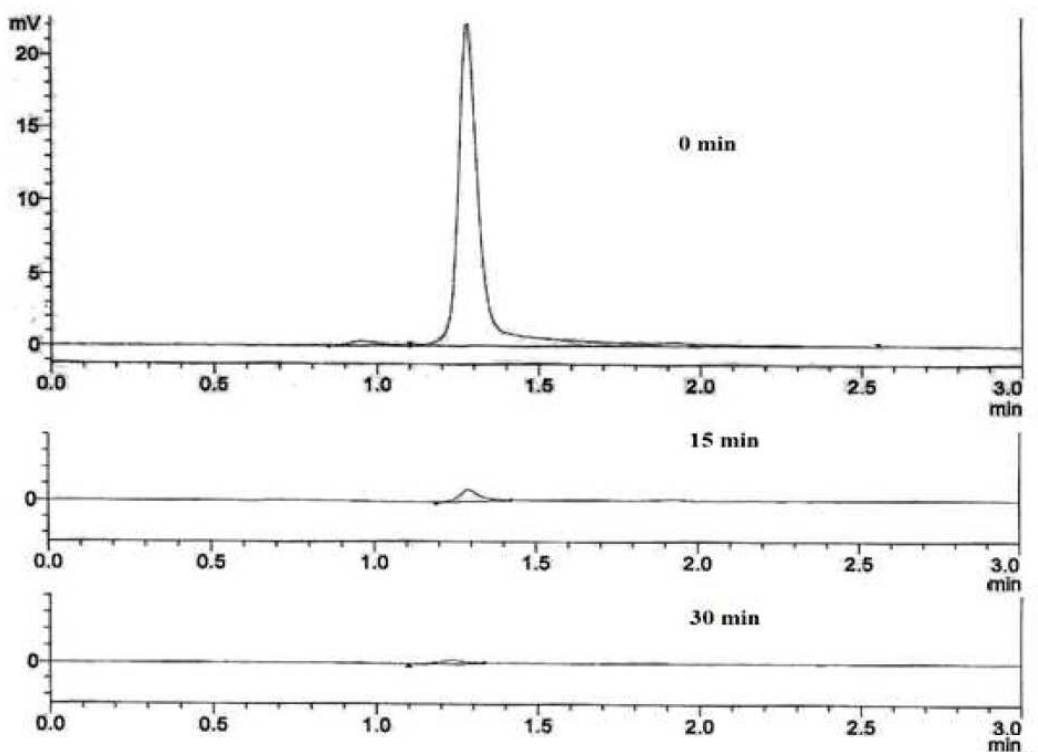

Figure 5. Chromatograms of RY17 degradation. [RY17 $]_{0}=5 \mathrm{mg} / \mathrm{L} ;\left[\mathrm{Fe}^{2+}\right]=0.04 \mathrm{mM}$; $\mathrm{I}=100 \mathrm{~mA} ; \mathrm{pH}=3 ; \mathrm{T}=22{ }^{\circ} \mathrm{C}$.

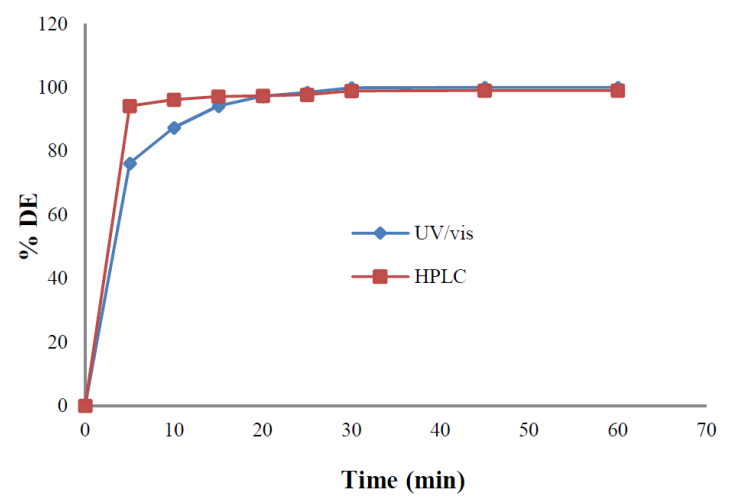

Figure 6. Evolution of the discoloration efficiency during RY17 electro-Fenton treatment, monitored by HPLC and by UV-visible spectroscopy. [RY17] $]_{0}=5 \mathrm{mg} / \mathrm{L}$; $\left[\mathrm{Fe}^{2+}\right]=0.04 \mathrm{mM} ;\left[\mathrm{Na}_{2} \mathrm{SO}_{4}\right]=50 \mathrm{mM} ; \mathrm{I}=100 \mathrm{~mA} ; \mathrm{pH}=3 ; \mathrm{T}=22{ }^{\circ} \mathrm{C}$. 
A comparison of the dye RY17 kinetics disappearance monitoring between HPLC and UV/vis was performed. Fig. 6 shows that RY17 disappearance is much faster than its discoloration, which suggests the presence of other colored intermediate molecules [17]. Indeed, RY17 has completely disappeared after 30 min electrolysis for HPLC-UV and UV/vis curves.

\section{Anodic oxidation process}

We have studied the degradation of an RY17 aqueous solution by anodic oxidation under the previously determined experimental conditions (ElectroFenton process), in the catalyst absence $\left(\left[\mathrm{Na}_{2} \mathrm{SO}_{4}\right]=50 \mathrm{mM}, \mathrm{pH}=3, \mathrm{C}_{0}=5\right.$ $\mathrm{mg} / \mathrm{L}, \mathrm{V}=500 \mathrm{~mL}, \mathrm{I}=100 \mathrm{~mA}$ ). Fig. 7 shows the discoloration efficiency of the pollutant (RY17), in terms of the electrolysis time for anodic oxidation process.

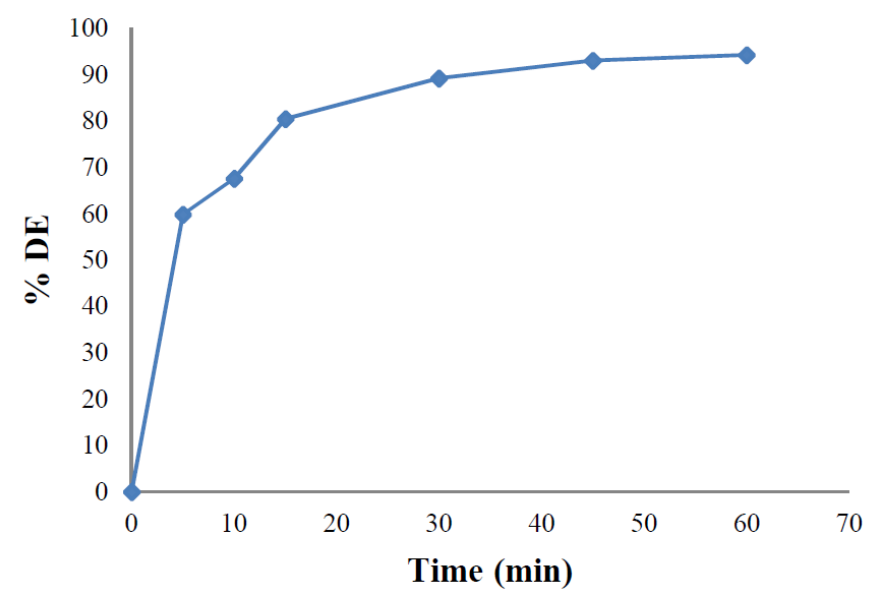

Figure 7. Evolution of the discoloration efficiency during RY17 anodic oxidation treatment. $[\mathrm{RY} 17]_{0}=5 \mathrm{mg} / \mathrm{L} ; \mathrm{I}=100 \mathrm{~mA} ;\left[\mathrm{Na}_{2} \mathrm{SO}_{4}\right]=50 \mathrm{mM} ; \mathrm{pH}=3 ; \mathrm{T}=22^{\circ} \mathrm{C}$.

\section{RY17 degradation by heterogeneous photocatalysis}

Effect of the initial dye concentration

The effect of the initial dye concentration was investigated by varying RY17 concentration from 5 to $40 \mathrm{mg} / \mathrm{L}$. Fig. 8 shows the change of the dye discoloration efficiency during the irradiation time, for the various RY17 initial concentrations.

Increasing the initial dye concentration, in the range between 5 and $40 \mathrm{mg} / \mathrm{L}$, decreases the photocatalytic degradation efficiency. The opposite effect is observed at low concentrations. Similar results were reported by other authors $[18,19]$. At high dye concentrations, the colored solution becomes compact and forms a screen, which makes the solution less transparent to UV light. Additionally, the dye's molecules can absorb a significant amount of UV light; as this latter does not reach the catalyst, the ${ }^{\circ} \mathrm{OH}$ radical formation is reduced. For low concentrations of the colored solution, this becomes easy to cross by the radial field, thus increasing the number of photons absorbed by the semiconductor and, consequently, its activity [20,21]. 


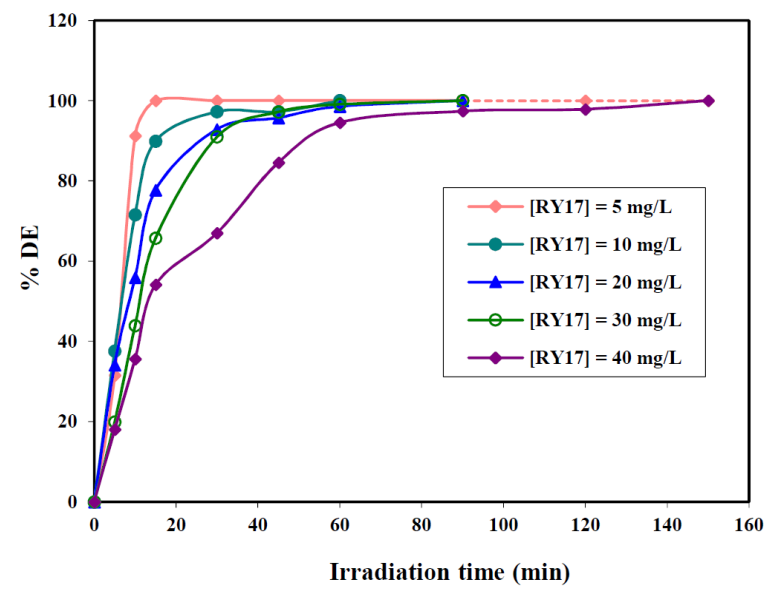

Figure 8. Effect of initial RY17 dye concentration on the photocatalytic efficiency. $\left[\mathrm{TiO}_{2}\right]=1 \mathrm{~g} / \mathrm{L} ; \mathrm{pH}_{\mathrm{i}}=5 ; \mathrm{T}=22{ }^{\circ} \mathrm{C}$.

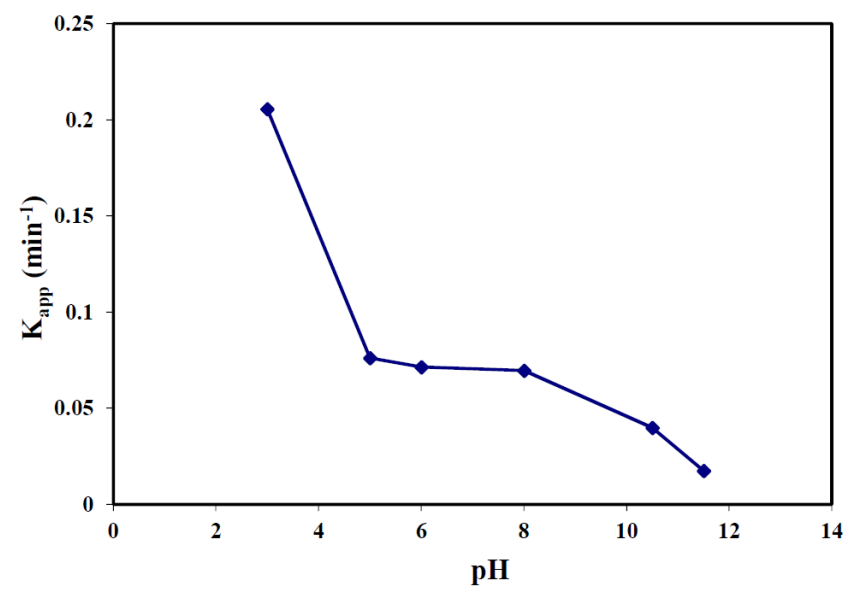

Figure 9. Influence of $\mathrm{pH}$ on RY17 dye degradation. [RY17 $]_{0}=30 \mathrm{mg} / \mathrm{L} ;\left[\mathrm{TiO}_{2}\right]=1$ $\mathrm{g} / \mathrm{L} ; \mathrm{T}=22^{\circ} \mathrm{C}$.

\section{Effect of $p H$}

The $\mathrm{pH}$ is an important operating variable in the wastewater. In the photocatalytic degradation systems, the $\mathrm{pH}$ value is also one of the factors that influence the percentage degradation. In a general way, when a compound is partially ionized, or the bearer of charged functions, it is necessary to consider the electrostatic interactions that can take place between the $\mathrm{TiO}_{2}$, or between its support and this compound. They depend on the $\mathrm{pH}$ of the solution that is going to be treated, on the adsorbent material's point of zero charge (PZC), and on the pKa of the compound that is going to be adsorbed [22].

The results of the experiments during the dye photocatalytic degradation at different $\mathrm{pH}$ values $(3,5,6,8,10.5$ and 11.5) are shown in Fig. 9. It illustrates the variation in the apparent rate constant $\left(\mathrm{K}_{\mathrm{app}}\right)$ as a function of $\mathrm{pH}$.

The $\mathrm{TiO}_{2}$ charge depends on the solution's $\mathrm{pH}$. It is known that the metal oxide particles in water readily react with the dye through a mechanism that can be described by the following chemical equilibria [23-25]:

$$
\mathrm{TiOH}+\mathrm{H}^{+} \rightarrow \mathrm{TiOH}^{+}
$$




$$
\mathrm{TiOH}+\mathrm{OH}^{-} \rightarrow \mathrm{TiO}^{-}+\mathrm{H}_{2} \mathrm{O}
$$

The $\mathrm{pH}$ at the zero charge point $\left(\mathrm{pH} \mathrm{PZC}\right.$ ) for this kind of $\mathrm{TiO}_{2}$ has been reported to be about 6.3 in value [26]. Thus, the surface of titanium dioxide is positively charged in an acidic medium, and it is negatively charged in a basic medium.

It appears from these results that the photodegradation is more important to an acidic $\mathrm{pH}$. This can be attributed to the electrostatic interactions between the catalyst surface and the dye's anionic groups at different $\mathrm{pH}$ values (Fig. 10). In an acidic medium, the anionic dye's groupings are strongly adsorbed on the surface of the positively charged catalyst, which leads to a better degradation. Whereas, with the $\mathrm{pH}$ increase, there will be a coulombic repulsion between the negatively charged support surface and the partial charges of the dye's anionic groups, and also with the hydroxyl ions, which prevents the formation of ${ }^{\circ} \mathrm{OH}$ hydroxyl radicals; consequently, the photocatalytic degradation efficiency decreases [27-29].
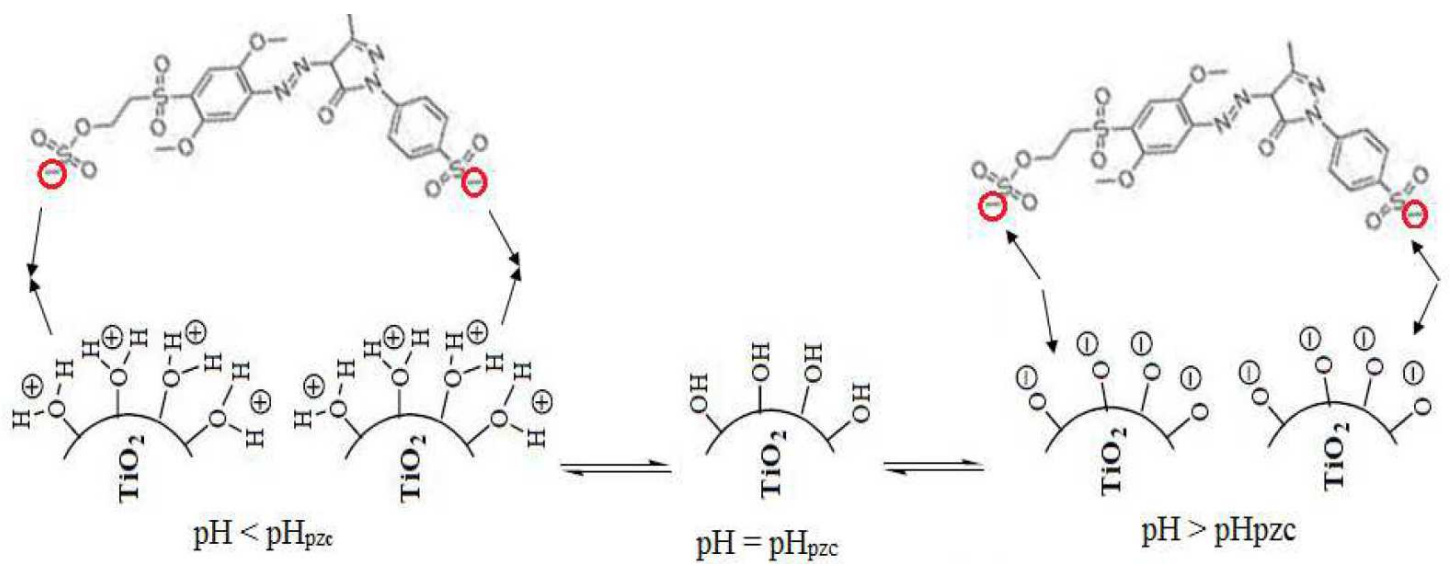

Figure 10. Interaction between the $\mathrm{TiO}_{2}$ groupings and the $\mathrm{RY} 17$ dye, as a $\mathrm{pH}$ function.

\section{Effect of $\mathrm{H}_{2} \mathrm{O}_{2}$ addition}

To highlight the hydroxyl radicals $\left({ }^{\circ} \mathrm{OH}\right)$ role in the dye degradation, we have realized photocatalytic tests in the presence of hydrogen peroxide, considered an important generation source of these radicals [30].

The influence of the $\mathrm{H}_{2} \mathrm{O}_{2}$ concentration on the photocatalytic activity of $\mathrm{TiO}_{2}$ for the RY17 photodegradation was studied by varying the $\mathrm{H}_{2} \mathrm{O}_{2}$ concentration. Fig. 11 shows the evolution of the initial dye disappearance rate.

The $\mathrm{H}_{2} \mathrm{O}_{2}$ addition accelerates the initial rate of the dye degradation, which reached a maximum for a hydrogen peroxide concentration equal to $3 \mathrm{~mol} / \mathrm{L}$. This increase in rate can be attributed to an increase in the ${ }^{\circ} \mathrm{OH}$ radicals concentration on the $\mathrm{TiO}_{2}$ surface, according to the following equation:

$$
\mathrm{H}_{2} \mathrm{O}_{2}+\mathrm{e}^{-} \rightarrow{ }^{\bullet} \mathrm{OH}+\mathrm{OH}^{-}
$$

In contrast, when the $\mathrm{H}_{2} \mathrm{O}_{2}$ concentration exceeds this maximum, for hydrogen peroxide large concentrations, the following reactions occur [31]: 


$$
\begin{aligned}
& \mathrm{H}_{2} \mathrm{O}_{2}+{ }^{\circ} \mathrm{OH} \rightarrow \mathrm{H}_{2} \mathrm{O}+\mathrm{HO}_{2}{ }^{-} \\
& \mathrm{HO}_{2}{ }^{\cdot}+{ }^{\circ} \mathrm{OH} \rightarrow \mathrm{H}_{2} \mathrm{O}+\mathrm{O}_{2}
\end{aligned}
$$

From these two reactions, it appears that a high concentration in $\mathrm{H}_{2} \mathrm{O}_{2}$ inhibits the photodegradation kinetics, because it consumes hydroxyl radicals $\left({ }^{\circ} \mathrm{OH}\right)$ and hydroperoxyles $\left(\mathrm{HO}_{2}{ }^{\circ}\right)$ necessary for the organic molecules photodegradation.

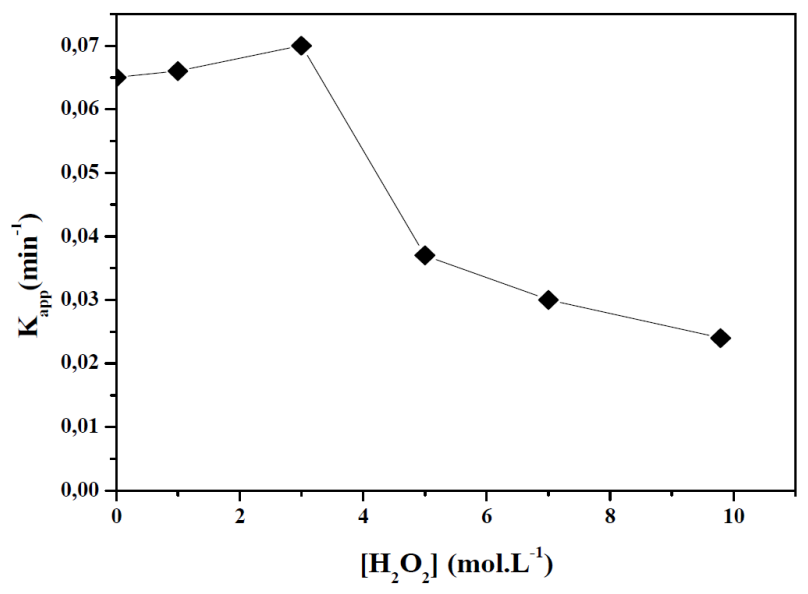

Figure 11. $\mathrm{H}_{2} \mathrm{O}_{2}$ influence on RY17 dye degradation. [RY17 $]_{0}=30 \mathrm{mg} / \mathrm{L} ;\left[\mathrm{TiO}_{2}\right]=1$ $\mathrm{g} / \mathrm{L} ; \mathrm{pH}_{\mathrm{i}}=5 ; \mathrm{T}=22{ }^{\circ} \mathrm{C}$.

Table 2. Optimal conditions for the different processes.

\begin{tabular}{|c|c|c|c|c|c|}
\hline Process & $\begin{array}{c}{\left[\mathbf{H}_{2} \mathbf{O}_{2}\right] \times \mathbf{1 0}^{-3}} \\
(\mathbf{m o l} / \mathbf{L})\end{array}$ & $\begin{array}{c}{\left[\mathbf{F e}^{\mathbf{2}}\right] \times \mathbf{1 0}^{-3}} \\
(\mathbf{m o l} / \mathbf{L})\end{array}$ & $\mathbf{p H}$ & $\mathbf{I}(\mathbf{m A})$ & {$\left[\mathbf{T i O}_{2}\right](\mathbf{g} / \mathbf{L})$} \\
\hline Fenton & 0.1 & 0.01 & 3 & - & - \\
\hline Photo-Fenton & 0.1 & 0.01 & 3 & - & - \\
\hline Electro-Fenton & - & 0.04 & 3 & 100 & - \\
\hline Anodic oxidation & - & - & 3 & 100 & - \\
\hline Heterogeneous photocatalysis & - & - & 3 & - & 1 \\
\hline
\end{tabular}

Comparison between Fenton, photo-Fenton, electro-Fenton, anodic oxidation and heterogeneous photocatalysis processes

To compare the performance of different advanced oxidation processes (Fenton, photo-Fenton, electro-Fenton, anodic oxidation and heterogeneous photocatalysis), a RY17 solution of $10 \mathrm{mg} / \mathrm{L}$ was treated in the optimal conditions for each process (Table 2).

Fig. 12 shows the efficiency discoloration of the pollutant (RY17) and the evolution of $\mathrm{Ln}\left([\mathrm{RY} 17]_{0} /[\mathrm{RY} 17]_{\mathrm{t}}\right)$, in terms of the electrolysis time for different advanced oxidation processes. It is clear from Fig. (12 (A)) that, during the application of heterogeneous photocatalysis treatment, RY17 disappeared to non-detectable levels after $30 \mathrm{~min}$ treatment, while it took up to $60 \mathrm{~min}$ with photo-Fenton and electro-Fenton processes. However, the discoloration efficiency obtained via Fenton and anodic oxidation processes in $60 \mathrm{~min}$, respectively, is of the order of 81.1 and $93.5 \%$. The relative efficiencies of all these processes are in the following order: heterogeneous photocatalysis > photoFenton $=$ electro-Fenton $>$ anodic oxidation $>$ Fenton . 
Fig. 12 (B) indicates that RY17 degradation with these different advanced oxidation processes followed pseudo first- order kinetics $\left(\mathrm{R}^{2} \geq 0.91\right)$. The experimental results revealed that the pollutant was most rapidly degraded by the heterogeneous photocatalysis process $\left(\mathrm{K}_{\mathrm{app}}=0.2 \mathrm{~min}^{-1}\right)$, followed by photoFenton $\left(\mathrm{k}_{\mathrm{app}}=0.126 \mathrm{~min}^{-1}\right)$, electro-Fenton $\left(\mathrm{k}_{\mathrm{app}}=0.122 \mathrm{~min}^{-1}\right)$, anodic oxidation $\left(k_{\text {app }}=0.076 \mathrm{~min}^{-1}\right)$ and Fenton $\left(k_{\text {app }}=0.061 \mathrm{~min}^{-1}\right)$ processes.

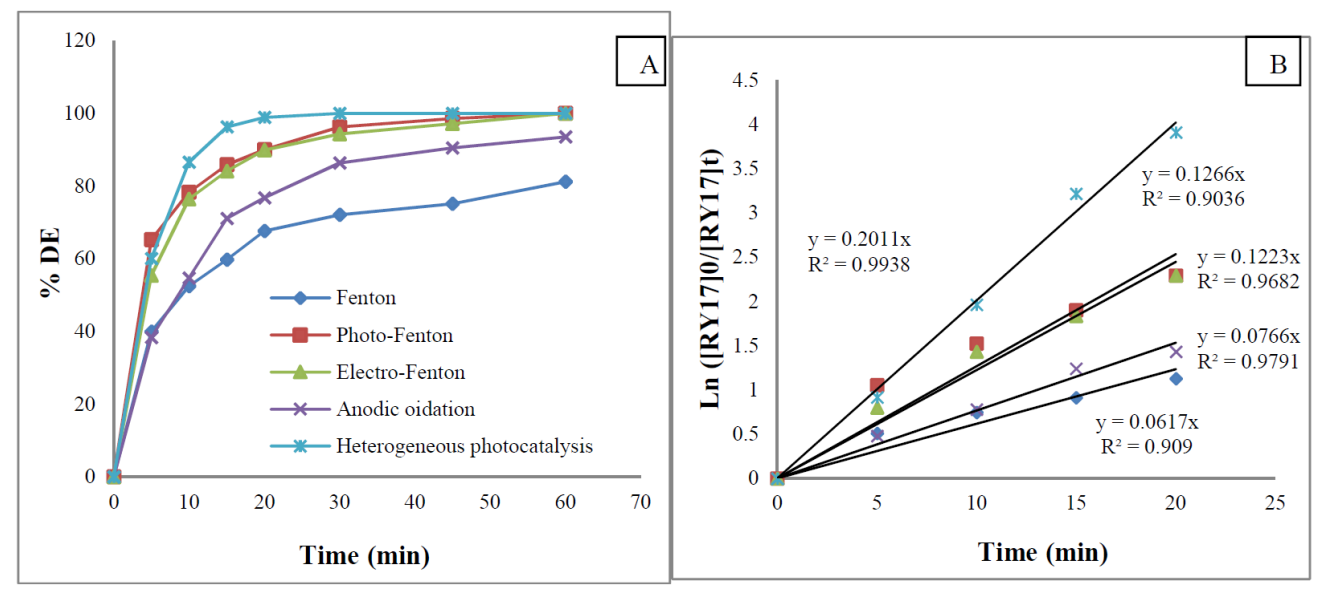

Figure 12. Evolution of the discoloration efficiency (A) and Ln ([RY17 $\left.]_{0} /[R Y 17]_{t}\right)(B)$ during RY17 treatment by the different advanced oxidation processes.

The enhancement of RY17 removal rate in the heterogeneous photocatalysis process was most probably caused by the significant generation of ${ }^{\circ} \mathrm{HO}$ via the use of $\mathrm{TiO}_{2}$ semiconductor as a catalyst, since it presents a favorable photocatalytic activity in dyes treatment and, in particular, in its anatase form $[32,33]$. Thus, it is related to the better RY17 dye adsorption onto this catalyst in an acidic medium $(\mathrm{pH}=3)$, which is probably due to the electrostatic attraction of $\mathrm{TiO}_{2}$ positive charge and the dye negative charge [26-28]. However, the photo-Fenton process is the fastest at the treatment start. This phenomenon can be explained by the introduction of $\mathrm{H}_{2} \mathrm{O}_{2}$ and $\mathrm{Fe}^{2+}$ at the treatment beginning, and by the irradiation through UV radiation. These two factors can significantly influence radicals ${ }^{\circ} \mathrm{OH}$ production [34].

The RY17 removal by the Fenton's reagent was due to the formation of ${ }^{\circ} \mathrm{OH}$ via Eq. (7). Moreover, $\mathrm{Fe}^{3+}$ in the solution was able to regenerate inside the reactor, when electric discharge and UV irradiation were used, allowing numerous $\mathrm{Fe}^{2+}$ react with $\mathrm{H}_{2} \mathrm{O}_{2}$ to generate ${ }^{\circ} \mathrm{OH}$. Ferrous ions are not depleted during the oxidation reaction, as shown in Eqs. (8), (9) and (12). Therefore, the electroFenton process and the photo-Fenton process can enhance RY17 oxidation rate [35].

The electro-Fenton process is more efficient than the anodic oxidation process. This is due to the production of hydroxyl radicals both by the Fenton reaction in a homogeneous medium and by water oxidation on the anode BDD surface, which is a high oxygen overvoltage electrode (Eqs. 7, 10). For the anodic oxidation method, the hydroxyl radicals are only formed at the anode surface (Eq. 10) [36]. 


\section{Conclusion}

In this work, RY17 dye degradation has been investigated by using several advanced oxidation processes: heterogeneous photocatalysis, Fenton, photoFenton, electro-Fenton, and anodic oxidation. Among all applied processes, heterogeneous photocatalysis process was found to be the most effective method. In this process, the oxidation efficiency was influenced by many factors, such as $\mathrm{pH}$, initial dye concentration and $\mathrm{H}_{2} \mathrm{O}_{2}$ addition. The optimal $\mathrm{pH}$ obtained for the best degradation was about 3.0 for the heterogeneous photocatalytic process. The complete RY17 dye degradation has been observed following 30 min treatment. Photo- Fenton and electro-Fenton processes were also effective in RY17 dye degradation, and the complete discoloration was achieved within the same time period (60 min).

Fenton process cannot completely degrade RY17 dye. However, we have found that UV light and electrons current (photo-Fenton and electro-Fenton) improved the degradation efficiency of the Fenton process.

The anodic oxidation process is a powerful method to the production of hydroxyl radical by the anode, but the electro-Fenton is the most effective process in RY17 degradation.

From the kinetic analysis, the reaction order for the five processes was found to be from the first order. The rate constant values at optimum operating conditions were found to be $0.061,0.076,0.122,0.126$ and $0.2 \mathrm{~min}^{-1}$ for Fenton, anodic oxidation, electro-Fenton, photo-Fenton and heterogeneous photocatalysis processes, respectively.

\section{References}

1. Pandey A, Singhand P, Iyengar L. Int Biodeterior Biodegrad. 2007;59:73-84.

2. Bafana A, Chakrabarti T, Devi S. Appl Microbiol Biotechnol. 2008;77:11391144.

3. Kusic H, Koprivanac N, Srsan L. J Photochem Photobiol A. 2006;181:195202.

4. Dukkanc M, Vinatoru M, Mason TJ. Ultrason Sonochem. 2014;21:846-853.

5. Garcia-Segura, Garrido JA, Rodriguez RM, et al. Water Res. 2012;46:20672076.

6. Khataee AR, Aleboyeh H, Aleboyeh A. J Exp Nanosci. 2009;4:121-137.

7. Chebli D, Fourcade F, Brosillon S, et al. Environ Technol. 2011;32:507-514.

8. Chia-Chi S, An-Tzu C, Bellotindos LM, et al. Sep Purif Technol. 2012;99:813.

9. Navarro RR, Ichikawa H, Tatsumi K. Chemosphere. 2010;80: 404-409.

10. Bellakhal N, Dachraoui M, Oturan N, et al. J Soc Chim Tunisie. 2006;8:223228.

11. Brillas E, Banos MA, Skoumal M, et al. Chemosphere. 2007;68:199-209.

12. Abdessalem AK, Bellakhal N, Oturan N, et al. Desalination. 2010;250:450455. 
13. Jacob RA. Nutr Res. 1995;15:755-766.

14. Sennaoui A, Sakr F, Dinne M, et al. J Mater Environ Sci. 2014;5:1406-1411.

15. Venkatadri R, Peters RW. Hazard Waste Hazard Mater. 1993;10:107-149.

16. Sennaoui A, Sakr F, Alahiane S, et al. Int J Mater Chem Phys. 2015;1:67-73.

17. Karkmaz M, Puzenat E, Guillard C, et al. Appl Catal B: Environ. 2004;51:183-194.

18. Davis RJ, Gainer JL, Neal GO, et al. Water Environ Res. 1994;66:50-53

19. Galindo C, Jacques P, Kalt A, Chemosphere. 2001;45:997-1005.

20. So CM, Cheng MY, Yu JC, et al. Chemosphere. 2002;46:905-912.

21. Daneshvar N, Salari D, Khataee A R. J Photoch Photobio A. 2003;157:111116.

22. Zhao H, Xu S, Zhong J, et al. Catal Today. 2004;93-95:857-861.

23. Kiriakidou F, Kondarides DI, Verykios XE. Catal Today. 1999;54:119-130.

24. Lachheb H, Puzenat E, Houas A, et al. Appl Catal B: Environ. 2002;39:7590.

25. Toor AP, Verma A, Jotshi CK, et al. Dyes Pigm. 2006;68:53-60.

26. Sun J, Qiao L, Sun S, et al. J Hazard Mater. 2008;155:312-319.

27. Kansal SK, Kaur N, Singh S. Nanoscale Res Lett. 2009;4:709-716.

28. Barka N, Qourzal S, Assabbane A, et al. Arab J Chem. 2010;3:279-283.

29. Barka N, Assabbane A, Nounah A, et al. J Hazard Mater. 2008;152:10541059.

30. Borello R, Minero C, Pramauro E, et al. Environ Toxicol Chem. 1989;8:9971002.

31. Qourzal S, Tamimi M, Assabbane A, et al. C R Chim. 2007;10:1187-1194.

32. Bessekhouad Y, Robert D, Weber JV. J Photochem Photobiol A. 2003; 157:47-53.

33. Le Roux H, Glasser L. J Mater Chem. 1997;7:843-851.

34. Tamimi M, Qourzal S, Barka N, et al. Sep Purif Technol. 2008;61:103-108.

35. Anotai J, Singhadech S, Chia-Chi Su, et al. J Hazard Mater. 2011;196:395401.

36. Oturan MA, Brillas E. Port Electrochim Acta. 2007;25:872-1904. 